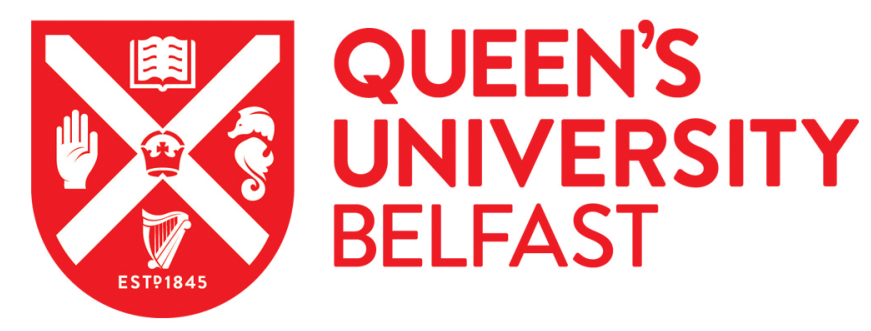

\title{
Brexit, bordering and bodies on the island of Ireland
}

McCall, C. (2018). Brexit, bordering and bodies on the island of Ireland. Ethnopolitics, 17(3), 292-305 . https://doi.org/10.1080/17449057.2018.1472425

\section{Published in: \\ Ethnopolitics}

\section{Document Version:}

Peer reviewed version

Queen's University Belfast - Research Portal:

Link to publication record in Queen's University Belfast Research Portal

\section{Publisher rights}

(C) 2018 The Editor of Ethnopolitics. This work is made available online in accordance with the publisher's policies. Please refer to any applicable terms of use of the publisher.

\section{General rights}

Copyright for the publications made accessible via the Queen's University Belfast Research Portal is retained by the author(s) and / or other copyright owners and it is a condition of accessing these publications that users recognise and abide by the legal requirements associated with these rights.

Take down policy

The Research Portal is Queen's institutional repository that provides access to Queen's research output. Every effort has been made to ensure that content in the Research Portal does not infringe any person's rights, or applicable UK laws. If you discover content in the Research Portal that you believe breaches copyright or violates any law, please contact openaccess@qub.ac.uk. 
Title: Brexit, Bordering and Bodies on the Island of Ireland

In Ethnopolitics, 2018

Article DOI: 10.1080/17449057.2018.1472425

\section{Author: Cathal McCall}

Professor of European Politics and Borders

School of History, Anthropology, Philosophy and Politics

Fellow of The Senator George J. Mitchell Institute for Global Peace, Security and Justice Queen's University

Belfast BT7 1NN

Tel. 0044 (0) 2890973378

Email: c.mccall@qub.ac.uk 


\section{ABSTRACT}

The Brexit campaign to withdraw the United Kingdom (UK) from the European Union (EU) was driven primarily by opposition to immigration and the freedom of movement of EU workers to Britain. Consequently, a central focus of Brexit was the perceived need for bordering, that is, the strengthening of Britain's borders as security barriers to prevent the movement of these unwanted outsiders to Britain. Such bordering has the potential to turn the tide against decades of debordering on the island of Ireland that was delivered by Europeanisation, the North South provisions of the Good Friday Agreement, and a wealth of cross-border cooperation initiatives. From an open Irish border vantage point this paper explores three Brexit bordering options: bordering the United Kingdom of Great Britain and Northern Ireland; bordering Britain; and bordering the isles of Britain and Ireland. The argument is that the least costly one is to confine Brexit bordering to the island of Great Britain.

Key words: Brexit, bordering, bodies, European Union, Britain, Island of Ireland, Good Friday Agreement, Europeanisation. 


\section{Introduction}

Traditionally, modern state territorial borders have been understood as parameters of possession, protection and exclusion in the national imagination. Within these borders the national group inhabits the territory, seeks to preserve it from incursion by unwanted outsiders, and sanctifies it as 'ours, not theirs' through its collective memories and associated emotions (Berezin, 2003, p. 7). Freedom of movement of labour across European Union (EU) borders captured a substantial segment of the British national imagination because it is held responsible for breaching the imagined parameters that give meaning to Britain, Britishness/Englishness and the contemporary 'British way of life'.

This paper examines Brexit bordering options to control the movement of bodies with human faces. It does so from the vantage point of an Irish border that has been the subject of Europeanisation, the North South provisions of the Good Friday Agreement, and a wealth of cross-border cooperation initiatives for two decades, resulting in a border that has been reconfigured from control barrier to connecting bridge.

\section{Debordering: Europeanisation, the Good Friday Agreement, and Cross-border Cooperation}

Fundamentally, Europeanisation encapsulates the creation, empowerment and influence of intergovernmental and supranational EU institutions. Europeanisation stresses concerted economic, legal, political and cultural action above the state, and intergovernmental cooperation between member states. It also encompasses cross-border cooperation between border regions, cities and localities. All have important implications for the meaning of sovereignty and the complexion of modern state borders within the EU (Sørensen, 1999; Wallace, 1999; Keating, 2004).

According to Vladimir Kolossov, borders configured as barriers are 'not only inefficient but objectively harmful to society and the economy' (Kolossov, 2005, p. 619). The 1986 Single European Act (SEA) was pivotal in reconfiguring member state borders from 'hard' tariff and security barriers to 'soft', open, free-flowing economic bridges. This reconfiguration was required in order to facilitate the flow of goods and people, and thus operationalise a European 'Single Market' (O'Dowd, 2002, p. 20). After the introduction of the European 
Single Market on 31 December 1992, border customs posts were abandoned, marking a visible and significant reconfiguration of member states' borders from 'hard' to 'soft'.

From 1989, the EU's structural funds initiative Interreg has promoted regional, city and local level cross-border cooperation in an effort to help address and erode 'from below' administrative, political, cultural and emotional obstacles to the creation of a Single Market (Phinnemore and McGowan, 2013, p. 304). On the island of Ireland, the EU Peace Programmes (from 1995) boosted such cooperation for the purpose of peacebuilding after conflict. These cross-border cooperation initiatives further progressed Irish border reconfiguration from barrier to bridge through their promotion of mobility, contact, communication and cooperation across it. The Peace programmes alone have provided funding of $€ 1,524$ million over almost two decades with cross-border cooperation prioritized. Two decades of hard and soft capital cross-border bridge-building has given substance to the notion of cross-border cooperation as conflict amelioration and helped to underpin the Good Friday Agreement's peacebuilding credentials (McCall, 2011)

The Agreement itself provided an infrastructural framework for cross-border cooperation on the island of Ireland. The North South (island of Ireland) structure was a key provision of the Agreement. It comprises of the North South Ministerial Council and its Implementation Bodies. Meetings of the North/South Ministerial Council have been concerned with North South cooperation in education, health, transport, agriculture, the environment and tourism, and have involved ministers with sectoral responsibility for each. Meanwhile, the Implementation Bodies promote North South cooperation in the areas of trade and business development, food safety, Gaelic and Ulster-Scots languages, aquaculture, waterways, and EU Programmes ${ }^{1}$. A limited company - Tourism Ireland - functions as a de facto implementation body to promote the island abroad as a tourist destination (Laffan and Payne, 2001; Coakley, Ó Caoindealbháin and Wilson, 2007).

While the Agreement nominally reaffirmed UK sovereignty over Northern Ireland in the formal-legal sense the North South institutions were clearly aimed at spreading the political

\footnotetext{
${ }^{1}$ The Special EU Programmes Body (SEUPB) manages EU programmes including Interreg and the EU Peace Programmes.
} 
and cultural substance of sovereignty beyond the state (Ruane and Todd 2001, p. 936). Thus, debordering the Irish border has involved constitutional ingenuity, reimagining state sovereignty and overcoming borders as barriers to mobility, contact, communication, cooperation and trade. It was bolstered by the eventual removal of the selective border security regime in the early 2000 s.

The launch of the European Single Market in 1992 and the onset of the Irish Peace Process in 1994 meant that border customs posts and border security checkpoint instillations were surplus to requirements. Secondary roads were re-opened and militarised sections of the Irish border gradually became demilitarised through the dismantling of British Army mountain top watchtowers in South Armagh and the closure of heavily fortified security bases along the border (Nash, Reid and Graham, 2013, pp. 109-111). The result is that the physical manifestation of the Irish border itself is hardly discernible save for a change in road markings and some 'Welcome to Northern Ireland' signs erected by the Northern Ireland Department of Regional Development in 2012, though many of these signs were removed, vandalised, defaced, or, in one instance, riddled with bulletholes ${ }^{2}$.

The continuing insurgent activity of small Irish republican splinter groups in the border region thereafter did little to disrupt the transformation of the Irish border from barrier to bridge. For example, in August 2009, one such group left a $300 \mathrm{~kg}$ bomb outside Forkhill, County Armagh, running a concealed command wire across the border into County Louth. A telephone warning was given but a week passed before British security forces located the bomb. Upon the discovery the UK Government asserted that British troops would not be reintroduced to secure the Irish border ${ }^{3}$.

Since the Good Friday Agreement, police cooperation across the Irish border has thrived through informal networks and force-to-force agreements, though largely without overarching transparent regulatory and accountability structures and processes. Primarily, its focus has been on organised crime and the activities of continuing republican insurgents.

\footnotetext{
${ }^{2}$ The latter at the border crossing between Ballyconnell, County Cavan (Ireland) and Derrylin, County Fermanagh (Northern Ireland). See http://www.irishnews.com/news/brexit/2017/12/08/news/brexit-borderassurances-are-politically-bulletproof-says-taoiseach-leo-varadkar-1206145/(accessed 08/12/2017). ${ }^{3}$ Irish Times, 10 September 2009 (accessed 10/07/2017).
} 
One example of this cooperation is the cross-border investigation into the murder of Paul Quinn by a criminal gang south of the border in 2007. An Garda Siochána (Irish Police) and Police Service of Northern Ireland (PSNI) officers operated as a team with Gardai conducting door-to-door enquiries in Northern Ireland (accompanied by PSNI personnel) while PSNI officers attended the interviews of suspects and witnesses in Ireland (Walsh, 2011). Another example of organic cross-border cooperation involving police officers was the prolonged search in 2016 for the body of a young man believed to have drowned in the river Erne which traverses the Irish border. Police and burgeoning numbers of people from both sides of the border joined forces in the search which ended after two months when the body was found. In the intervening period, strong bonds of friendship were forged with one police officer commenting 'we saw these people realising that there is very little actually separating us' (Pollak, 2016).

From the perspective of bodies with human faces, the benefits of debordering the Irish border cannot be over-estimated. The day-to-day cross-border mobility, contact, communication and cooperation among people has been beneficial to society, not least through its significance in supporting the Irish Peace Process, especially when unionistnationalist political disagreements impacted upon the functioning of the Good Friday Agreement institutions (McCall, 2011).

\section{Rebordering: Brexit}

On the broader European and global fronts, the EU's debordering impulse of the 1990s was challenged by twenty-first century dramatisations that gave rise to increased perception of risks and threats from international terrorism and contested immigration. The EU response was to attempt to create the EU as a 'gated community'. It deploys sophisticated selection mechanisms which determine the entry of individuals, the aim being to protect European citizens from multifarious threats emanating from beyond the gates (van Houtum and Pijpers, 2007, p. 303). In the process, cross-border cooperation may be understood to have shifted from being a debordering dynamic towards a bordering one through the increased emphasis on border securitisation across the EU's external frontier (Andreas, 2003; Walters, 2006; McCall, 2014). Thus, while the EU has 'sought to valorize transnational spaces through 
cross-border and inter-regional co-operation programmes' (Keating, 2012, p. 30), its twentyfirst century emphasis on 'security' has translated into building an EU external frontier as a barrier against multifarious threats.

Borders remain the principal foci for securitising mobility (Amoore, 2006). Indeed, many EU member states have attempted to take border matters into their own hands and secure their state borders in the face of contested immigration and terrorist attack. These attempts have been understood as performances in reasserting the authority of the state (Peoples and Vaughan-Williams, 2015, p. 175). They confirm that debordering and rebordering are competing and overlapping processes in the EU (Amilhat Szary and Giraut 2015, p. 4).

The campaign for the United Kingdom (UK) to leave the EU - commonly referred to by the acronym 'Brexit' (from 'Britain's exit') - was invigorated by concerns, prejudices, fears and insecurities relating to the mobility of EU workers, as well as a media spotlight on contested immigration, in the contexts of a prolonged period of economic austerity and the EU's Mediterranean migration/refugee crisis which spiked in 2015.

The Brexit referendum campaign focused on the nexus between bordering and security. Its primary objective was to establish a hard security border regime in order to prevent the movement of unwanted outsiders to Britain, including those coming from within the EU, and thus remove an 'existential threat' to British identity (Buzan, 1993).

The Brexit referendum on 23rd June 2016 resulted in a majority of 52 per cent in favour of the UK exiting the EU. Michael Keating detected three groups under the Brexit umbrella: the 'Europeans' who prioritise access to the European single market without the political consequences ${ }^{4}$; the 'Little Englanders' who oppose EU membership or affiliation; and the 'Globalists' who resent EU regulation and believe that the UK can become a global economic superpower in its own right (Keating, 2016). However, objection to the EU's freedom of movement of labour principle was a key motivating factor for Brexiters of all hues.

\footnotetext{
${ }^{4}$ The 'Brexit Europeans' support for the free movement of capital and commodities across the EU is in stark contrast to their objections to the free of movement of labour. Therein lies an inherent contradiction since there is an inevitable connection between market integration and the free movement of labour to service that market in the neo-liberal economic model.
} 
The threat from contested immigration has made regular headlines in the British media, particularly in the right-wing tabloid press. Calais, Sangatte and 'the Jungle' have been portrayed as sites of perennial threat for Britain and 'the British way of life' ${ }^{5}$. Chaotic scenes of contested migrants attempting mass crossings of the English Channel via the Channel Tunnel have provided the necessary drama for prioritising this issue in British politics. Reacting to this drama in July, 2015, the then UK Prime Minister David Cameron heightened it further when he proclaimed that '... you have got a swarm of people coming across the Mediterranean, seeking a better life, wanting to come to Britain because Britain has got jobs, it's got a growing economy, it's an incredible place to live' (my emphasis) ${ }^{6}$. Such a 'speech act' has been identified as an important component of a securitisation process that emphasises bordering (Waever, 1995): 'the swarm' is the threat; hard security borders are the answer to that threat.

The wider issue of the post-2004 arrival of 'legitimate' mobile workers from Central Eastern Europe is the prejudicial bedrock upon which this securitisation process is based. According to Cameron: '... the bigger issue today is migration from within the EU. Numbers that have increased faster than we in this country wanted ... at a level that was too much for our communities, for our labour markets' ${ }^{7}$

According to Roger Liddle, the Brexit campaign was 'the remorseless logic of Conservative division on the European question' (Liddle, 2015, p. 5). It was a direct consequence of the strength of Eurosceptic lobbies within the Party and beyond it. With Cameron leading a Conservative majority government after May 2015, Brexit became firmly placed on the UK political agenda with the EU freedom of movement of labour principle becoming an important motivating factor of the campaign (O'Ceallaigh and Gillespie, 2015, p. 223).

In the UK, the state security bordering process was already well advanced, symbolised by large signs declaring 'The UK Border' in the international arrivals halls of UK airports. The UK

\footnotetext{
${ }^{5}$ See, for example, http://www.express.co.uk/news/uk/566380/Britain-braces-more-immigrants-Calaisrefugee-camp-Sangatte-2, and http://www.dailymail.co.uk/news/article-2174296/The-return-Sangatte-Insidenew-mini-migrant-camp-close-Calais.html (both accessed 23/06/2016).

${ }^{6}$ http://www.bbc.co.uk/news/uk-politics-33716501 (accessed 04/06/2016).

7 http://press.conservatives.com/post/98882674910/david-cameron-speech-to-conservative-party (accessed 02/01/2016).
} 
border security regime is a sophisticated response to perceived threats emanating from Outre-Mer and is largely focused on 'border portals' and 'choke points' - airports, ports and the Channel Tunnel. The Channel Tunnel is a particular point of interest for those concerned with bordering Britain to halt contested immigration. Unlike a land border, the Channel Tunnel is a singular port of entry or 'choke point' through which all vehicles, goods and people have to pass and, as such, should present a relatively straight-forward site for the exercise of a security regime (Anderson with Bort, 2001, p. 184). A greater challenge is patrolling the maritime borders around Britain, especially when it was revealed that the Border Force fleet numbered only five sea-worthy vessels ${ }^{8}$.

The British border security regime also involves activities in an electronic/intelligence cyberborder sphere, with nodes that extend to the European continent, and wherein the biometric passport - 'the border in the pocket' - and the smartphone with GPS supersede many traditional functions of the human border guard (Häkli, 2015, p. 93).

Yet, Brexiters remained unimpressed by 'the border in the pocket' or by the fact that the UK border zone extends territorially to the European continent with UK border guards, replete with a formidable armoury of electronic border control paraphernalia - information databases, x-ray machines, electronic fingerprinters, body scanners, heat-seeking cameras, robots, and probes - stationed in Boulogne, Brussels, Calais, Coquelles, Dunkerque, Frethun, Lille and Paris. They are blind to the work of border intelligence agents, such as Airline Liaison Officers who advise foreign law enforcement agencies on the potential cross-border movement of people deemed to be 'illegitimate' or 'undesirable' travellers (VaughanWilliams, 2009). And it is, of course, a top priority of British Intelligence agencies, engaged in the clandestine governance of border control, to remain below the radar of politicians, the media, and the general public.

Conversely, Brexiters have enjoyed a high profile in British politics and the media; their cause helped by the Mediterranean migration/refugee crisis, by arresting television images of contested migrants attempting to cross the English Channel, and by the Polski Smak (Polish Flavour) of the rapidly changing twenty-first century British high street. In other

\footnotetext{
${ }^{8}$ At bbc.co.uk/news/uk-politics-26960905 (accessed 04/08/2016).
} 
words, efforts to create an eclectic border zone around Britain through offshore bordering practices did not neutralise the perceived threat posed by legitimate mobile EU workers to the contemporary 'British way of life'.

The 'bring back control' quest of Brexiters demands the creation of clear, hard security borders that prove to be impenetrable for unwanted outsiders, including those from within the EU. But where would the Brexit security border run?

\section{Option 1: Bordering the United Kingdom of Great Britain and Northern Ireland}

Britain's front door to the European continent is heavily alarmed and would readily serve many of the bordering requirements of Brexit. Britain being an island lends itself to bordering. However, the UK's back door to Ireland is wide open. The barely perceptible Irish border is the only land border that the UK shares with another member state ${ }^{9}$.

Prior to the Brexit referendum, then British Home Secretary Theresa May claimed that 'it is inconceivable that a vote for Brexit would not have a negative impact on the North/South [Irish] Border, bringing cost and disruption to trade and to people's lives ${ }^{\prime 10}$. After becoming Prime Minister, May acknowledged that '... of course Northern Ireland will have a border with the Republic of Ireland, which will remain a member of the European Union' ${ }^{11}$.

Post-Brexit, Ireland will continue as an EU member state and abide by its freedom of movement obligations. So it is, therefore, logical to assume that the Irish border will be the principal foci for the British Government's effort to 'bring back control'. However, this assumption is problematic, not least because the Irish border meanders for approximately $500 \mathrm{~km}$ through towns, townlands, mountains, loughs, bogs, fields, farms and houses across the island of Ireland, has hundreds of crossing points, and was the subject of agitation and violence from its consolidation in 1925 until its reconfiguration from barrier to bridge in the

\footnotetext{
${ }^{9}$ Gibraltar shares a land border with Spain. However, under the Treaty of Rome (1973) and the UK Act of Accession (1973) Gibraltar is classified as a dependent territory of the UK and not as a member of the UK. 10 Financial Times, 25 July 2016 (accessed 28/07/2017).

${ }^{11}$ The EU, being a customs union, requires border customs posts to be established between the EU and nonmembers. This is the case between the EU and Norway which is the subject of the most advanced EU free trade agreement with a non-member state.
} 
1990s. The island of Ireland has the densest cross-border road network in Europe (Leary, 2016). Additionally, it is unruly: key arterial roads can cross the border more than once. For example, the direct route from Cavan Town (in Ireland) to Dungannon (in Northern Ireland), through the Drummully Salient, crosses the border no less than 5 times.

When the Northern Ireland 'Troubles' shifted from urban centres to the Irish border region in the 1980s British security forces had difficulty coping with local mobile Irish Republican Army (IRA) units whose members had an in-depth knowledge of the complex border terrain (Patterson, 2013). Additionally, the border security regime was partial because the British Government recognised that a continuous securitised border would play into the hands of Irish republican insurgents since it would have risked further alienating the Irish nationalist population. In other words, the relative lack of border security was due to the fact that there was 'no political will at Westminster' for its imposition because of the concern that such a move would further stir political and militant Irish nationalism (Rose, 1983, p. 3).

With 'no political will at Westminster' to secure the Irish border at the height of the Northern Ireland 'Troubles', such an undertaking after Brexit would be a demonstration of abject political neglect. All the more so because the reconfiguration of the Irish border from barrier to bridge - through the removal of security checkpoints and customs posts, as well as the Good Friday Agreement's promotion of North South (Belfast-Dublin) and cross-border cooperation - has been an important element in British-Irish peacebuilding.

Conceivably, Brexit bordering could entail the reintroduction of customs, agri-food inspection and immigration checkpoints on cross-border arterial routes, the closure of hundreds of secondary cross-border roads (that were reopened in the 1990s courtesy of EU Interreg funding $)^{12}$, and the establishment of a border security regime to support vulnerable customs and inspection officials and infrastructure.

Technology could be applied to the management of Irish border security. Devices such as motion sensors, scanners, infra-red and surveillance cameras, as well as migration databases could be deployed in that management. Indeed, the Legatum Institute - the

\footnotetext{
${ }^{12}$ Such roads connect border cities, towns and villages including Derry, Strabane, Lifford, Pettigo, Belleek, Belcoo, Blacklion, Swanlinbar, Aghalane, Belturbet, Newtownbutler, Clones, Aughnacloy, Middletown, Dundalk and Newry.
} 
influential Brexit 'think tank' in London - proposed the 'persistent surveillance of the border region` by Unmanned Aerial Vehicles (drones) after Brexit ${ }^{13}$ (Singham et al, 2017, p. 28). However, to suggest that technology would render a post-Brexit Irish border 'invisible' is rejected by border technology experts (Taylor, 2017). Without the human border guard, sensors, scanners, cameras and databases serve as little more than recording and counting devices of border crossings (Broeders, 2011, pp. 40-41). Additionally, in the case of the unwieldy Irish border, technological infrastructure on cross-border roads would be no less vulnerable to destruction than 'Welcome to Northern Ireland' signs unless it was protected by human border patrols.

In its EU-UK Brexit negotiations Position Paper Northern Ireland and Ireland (2017) the British Government stated that it wanted the Irish border to remain 'as seamless and frictionless as possible'. If this statement reflected a desire to maintain the status quo, namely, an open border with the free flow of goods and people across it, then there is an obvious clash with the British Government's greater desire: leaving the EU (including the Single Market and Customs Union) and 'taking back control' of the free movement of people. Since Brexit has been inspired by the desire to curb freedom of movement of labour from the European continent it does not seem plausible that the UK Government could entertain the continuation of an open Irish border. Nigel Lawson, the former UK Chancellor of the Exchequer and chairman of the Vote Leave campaign, conceded that 'there would have to be border controls'. Dominic Raab, Parliamentary Under Secretary of State at the Ministry of Justice between May 2015 and July 2016, also admitted that 'If you're worried about border controls and security ... you couldn't leave a back door without some kind, either of checks there with any country or assurances in relation to the checks that they're conducting, obviously'. ${ }^{14}$

\footnotetext{
${ }^{13}$ The Institute also proposed transforming the SEUPB into a border security agency, post-Brexit (Singham et al, 2017, p. 8).

14 Irish Times, 11 April 2016. At http://www.irishtimes.com/news/ireland/irish-news/brexit-could-lead-toirish-border-controls-tories-warn-1.2605627 (accessed 22/08/2016).
} 


\section{Option 2: Bordering Britain}

Arguably, the Irish border that was made manifest between 1921 and 1925 was an imperial frontier because it was imposed by the British Empire in retreat (Anderson and O'Dowd, 2005). Eventually, the border began to resemble a state border through the UK shift from imperial power to national state, state-building in Sáorstat Éireann (Irish Free State), and the consolidation of an British unionist administration in Northern Ireland. However, the reconfiguration of the Irish border from imperial frontier to state border remained partial. The Common Travel Area between Britain and Ireland may be understood as an imperial residue of the UK state and a symbol of Ireland's neo-colonial dependency on Britain ${ }^{15}$. A benign understanding of the Common Travel Area is that it enables freedom of movement for British and Irish citizens between Britain and Ireland. In effect, however, freedom of movement in the Common Travel Area has been predicated on the coordination of immigration policies operated by the UK and Ireland to secure what was called the 'common outer perimeter' of the isles of Britain and Ireland (Meehan, 2014).

Despite the formation of the Sáorstat Éireann in 1921 and its exit from the Commonwealth in 1949, citizens of the 'Free State' (to 1937) and then of the Republic of Ireland (from 1949) retained the legal right to enter Britain and avail of the same rights as British citizens. Echoes of this British imperial consciousness reverberated in Section 2 of the UK's 1949 Ireland Act: 'Notwithstanding that the Republic of Ireland is not part of His Majesty's Dominions, the Republic of Ireland is not a foreign country for the purposes of any law in force in any part of the UK' S. $2(1)^{16}$. The 1949 Ireland Act remains in force.

This did not mean that the common travel area was insulated from higher security concerns. In response to security threats 'bordering Britain' was triggered without a qualm. In 1940 travellers from the island of Ireland were required to carry passports or limited travel documents for 'war-work' in order to enter Britain. A common travel area between Britain and Ireland was not reinstated fully until 1952 (Meehan, 2000, p. 26). In 1974, the introduction of the Prevention of Terrorism (Temporary Provisions) Act gave the British

\footnotetext{
${ }^{15}$ Elizabeth Meehan has pointed out that The Common Travel Area was referred to as "the common travel area" in policy documents before it became The Common Travel Area through international recognition bestowed on it by the 1997 Treaty of Amsterdam (2000, p. 1).

16 http://www.legislation.gov.uk/ukpga/Geo6/12-13-14/41 (accessed 10/02/2017).
} 
Home Secretary the power to prevent individuals moving from Northern Ireland to Britain and also to deport individuals from Britain to Northern Ireland:

If the Secretary of State is satisfied that -

a) any person (whether in Great Britain or elsewhere) is concerned in the commission, preparation or instigation of acts of terrorism, or

b) any person is attempting or may attempt to enter Great Britain with a view to being concerned in the commission, preparation or instigation of acts of terrorism,

the Secretary of State may make an order against that person prohibiting him from being in, or entering, Great Britain. ${ }^{17}$

Passengers at the 'Belfast Gate' of Britain's airports were familiar with the intrusion of border control paraphernalia decades before the experience became widespread after the drama of the $11^{\text {th }}$ September 2001 Islamic jihadist attacks on the United States of America. Britain's border within the UK, combined with the permeability of the UK's land border with Ireland and Westminster's willingness to allow Northern Ireland to secede unilaterally (unlike Scotland or Wales) in the event of a majority in Northern Ireland approving such a move, is thus problematic for the idea of a UK border that is coterminous with the UK state. Britain is the de facto state and its borders are 'fuzzy' (Rose, 1983, pp. 31-2).

A Brexit quest to secure borders and identify and exclude unwanted outsiders raises the issue of whether Ireland is to be regarded as a 'foreign country'. If the answer is 'yes' then the continued existence of the Common Travel Area between Britain and Ireland is called into question. However, a Brexit border security regime may also exclude Northern Ireland given the economic expense, practical difficulties and political risks involved in attempting to secure the Irish border. In a Brexit bordered Britain passengers travelling from the Ireland to Britain would be required to produce some form of identification at ports and airports in order to be processed in the British border control system and gain entry into Britain.

\footnotetext{
17 Part II Exclusion Orders, 3:3, Prevention of Terrorism (Temporary Provisions) Act 1974 at http://cain.ulst.ac.uk/hmso/pta1974.htm (accessed 19/05/2017).
} 
Travellers departing from Northern Ireland to Britain would receive the same treatment given the porous nature of the Irish border.

This would mean that Britain's border portals (at ports and airports) would become the foci for Brexit securitisation. The requirement to produce a form of identification other than a passport at a Britain's border security portal checkpoints would help to soothe Ulster British national identity sensitivities. Brexit's totemic 'bring back control' of immigration and the disbarment of unwanted outsiders from Britain indicates that the performance of such checks would have to take place at Britain's border portals in any case. Passing the burden of immigration restriction wholly to employers, landlords and the education sector is unlikely to satisfy the controlling urges of Brexiters.

This 'Bordering Britain' option is attractive on 3 counts: firstly, it would honour a crossborder, cross-community democratic wish articulated in the oft repeated refrain in the political domain, namely, 'no one wants to see a hard border' on island of Ireland; secondly, it would be practically easier and economically less costly to establish and manage; and thirdly, it would avoid the risk of a return to the violence associated with a hard Irish border, as noted by the PSNI's Deputy Chief Constable ${ }^{18}$; . As Kapka Kassabova accurately observes, 'an actively policed border is always aggressive: it is where power suddenly acquires a body, if not a human face, and an ideology' (2017, p. xvi). In the case of the Irish border, bordering requires bodies with (concealed) human faces that would re-dramatise the conflicting British and Irish nationalist ideologies that two decades of debordering have helped to ameliorate.

The logic of Brexit is that Britain's borders may well retreat to Britain, and possibly to England and Wales thereafter, in the quest to render them, clear, secure, and impenetrable to unwanted outsiders. Such bordering would reflect the British national imagination. Though the Scottish imagined community may demur, the British national imagination has the borders of the UK fixed firmly on Britain - This Sceptred Isle. Political psychologists have found that, in the British context, 'allusions to the geographical boundaries of imagined community [the island] may be used as a substitute for reference to the common and

\footnotetext{
${ }^{18}$ See https://www.newsletter.co.uk/news/crime/post-brexit-border-infrastructure-obvious-target-fordissident-republican-terrorists-1-8280713 (accessed 08/12/2017).
} 
distinctive character or "identity" of the population' (Abell, Condor and Stevenson, 2006). 'This Sceptred Isle' and the 'White Cliffs of Dover' pervade heroic, romantic and (banal) nationalist readings of British history (Billig, 1995). Popular television and radio programmes such as the ten-week BBC Radio 4 series This Sceptred Isle, the long-running BBC comedy Dad's Army, as well as its seemingly endless documentary series Coast have helped to inculcate an idea of Britain in the British communal imagination. This Sceptred Isle - from Land's End to John O'Groats - remains the key reference point for Britain, British identity and the 'British way of life'.

Northern Ireland does not feature on this 'mainland' British radar. When British broadcasters announced the inclusion of seven political parties - Conservative, Labour, Liberal Democrat, UKIP, SNP, Green, and Plaid Cymru - in the line-up for the 2015 General Election televised debates, Northern Ireland parties were overlooked. When the then Democratic Unionist Party (DUP) leader, Peter Robinson, complained that his party was the fourth largest at Westminster and should, therefore, be included, he was rebuffed by the BBC's Director General, Tony Hall, on the grounds that the party political structure in Northern Ireland differs significantly from the rest of the $\mathrm{UK}^{19}$. In his effort to avoid the debates altogether the then Prime Minister David Cameron cited the initial exclusion of the Greens, not the DUP, as grounds for his non-participation.

According to Elizabeth Meehan, 'Great Britain being an island is still crucial to the outlooks of governments on the maintenance of frontier controls' (Meehan, 2000, p. 60). British public opinion reflects the position of UK Governments on Britain's borders. In an ICM opinion poll published in the Guardian newspaper on 21 August 2001, the question posed to a sample of Britons in Britain was: 'Do you think Northern Ireland should be part of the UK? 26 per cent responded that it should remain part of the UK, 41 per cent that it should be joined with Ireland, and 33 per cent responded 'don't know'20.

Needless to say, unionists in Northern Ireland do not share that outlook. Arlene Foster (DUP, Leader) appeared to be aware of the possibility of Brexit bordering Britain when she

\footnotetext{
19 http://www.bbc.co.uk/news/uk-politics-31029232 (accessed 04/06/2016).

${ }^{20}$ There has not been a similar poll conducted since 2001. However, there are no indicators to suggest that the percentages revealed in the 2001 poll have shifted significantly in the interim.
} 
declared: 'There must be no internal borders within the UK' ${ }^{21}$. After entering into a 'confidence and supply' supportive arrangement with the post-2017 General Election minority Conservative government it appeared that the DUP's opposition to bordering Britain was shorn up by that government. Its Department for Exiting the European Union rejected the idea of locating Brexit customs controls at ports and airports stating 'we cannot create a Border between Northern Ireland and Great Britain' (Staunton, 2017). Yet, Phase 1 negotiations on Brexit entertained the option of ports and airports in Britain and Northern Ireland becoming the foci for customs and border inspections that would ensure the integrity of the Single Market, to which Northern Ireland would be 'fully aligned'. A nontariff deal between the Northern Ireland Executive and the UK Government on Irish goods entering Britain also remained a possibility. Arguably, this scenario is intimated in the linguistic contortions of the 'Joint report from the negotiators of the European Union and the United Kingdom Government on progress during phase 1 of negotiations under Article 50 TEU on the United Kingdom's orderly withdrawal from the European Union' (European Commission, 8 December 2017, paragraphs 49 and 50). Such a scenario would avoid the economic damage of a hard Irish border to integrated sectors on the island, notably the agri-food sector. In any case, state security checks on bodies with human faces entering Britain through its ports and airports remained beyond the pale of these negotiations, even though freedom of movement of EU workers was a key driver of Brexit.

\section{Option 3: Bordering the Isles of Britain and Ireland}

As the operation of the Common Travel Area testifies, a high level of cooperation and information-sharing between the UK and Irish electronic border control systems is evident and could form the basis for the development of a hard border around the isles of Britain and Ireland. In terms of intelligence and state security it may be assumed that information sharing between relevant Intelligence agencies in Britain and Ireland is already highly developed.

${ }^{21}$ Financial Times, 25 July 2016 (accessed 28/07/2017). 
Brexit raises the possibility of an intensification of UK-Ireland security cooperation to the ends of bordering the isles of Britain and Ireland and excluding unwanted outsiders, including non-Irish EU citizens. However, such a course of action would present the Irish Government with serious questions, not least one regarding Ireland's continued membership of the EU. Any attempt to restrict the mobility of EU workers runs counter to the EU's freedom of movement of labour principle contained in the Acquis Communautaire. This did not stop most pre-2004 member states, including France and Germany, from imposing their own temporary restrictions on workers from the 2004 Enlargement states: restrictions can be maintained for a maximum of 7 years after accession. The difference is that the proposition of UK-Ireland bordering to control freedom of movement of people suggests the imposition of permanent restrictions. Such an eventuality would position Ireland for an 'Irexit'.

In the context of Treaty of Lisbon (2009), Hugo Brady, Centre for European Reform, claimed that: 'Following on from Ireland's decision to follow London and opt out of key parts of the reform treaty, it increasingly looks like Ireland is a small country latched to Britain like a koala on justice [and home affairs] issues ...22 . However, leaving the EU is an entirely different proposition for a small state like Ireland that has been unremittingly committed to EU membership principles, reaping 40 years of benefits in terms of acquiring sovereignty, developing infrastructurally, and opening culturally ${ }^{23}$ (Laffan and O'Mohony, 2008). Moreover, as the former British Labour MP and Minister for Europe, Denis MacShane, has pointed out, Brexit would absolve the UK government from the obligation to treat Ireland with the status, respect and reciprocity that it acquired upon both states becoming EC member states in 1973 (MacShane, 2015, p. 20). An 'Irexit' would further expose Ireland to the vagaries of British politics in a new asymmetrical relationship with its much larger and

\footnotetext{
22 www.cer.org.uk/articles/52_brady.html (accessed 06/12/2016).

${ }^{23}$ The implications of Brexit for the island of Ireland alarmed the Irish Government. For example, in a speech at Queen's University, Belfast on the 4th of August, 2017, the Irish Taoiseach (Prime Minister) Leo Varadkar highlighted the challenges of Brexit for the island of Ireland, particularly those relating to the Irish border (Garry, 2017). There have also been a number of Irish scholarly interventions on the subject. See, for example, Kilcourse, 2013; O'Ceallaigh and Kilcourse, 2013; and O'Ceallaigh and Gillespie, 2015.
} 
more powerful neighbour. On the possibility of an Irexit a former Taoiseach (Irish Prime Minister) commented: 'we're mad, but we're not that mad' $^{24}$.

\section{Conclusion}

During the Northern Ireland 'Troubles' the political risks of a continuous and 'seamless' (in the security barrier sense) Irish border were recognised by the British Government. That border has undergone a twenty year reconfiguration - driven by Europeanisation, the North South provisions of the Good Friday Agreement, and an avalance of cross-border cooperation initiatives - that has rendered it open and free flowing for unhindered mobility, contact, communication, cooperation and trade.

The Brexit campaign was primarily concerned with 'bringing back control' of the movement of unwanted 'outsiders' to Britain, including EU citizens from mainland Europe. Bordering is the principal mechanism for asserting such control. Therefore, the key Brexit question is: Where to implement bordering? This paper has explored three options: bordering the United Kingdom of Great Britain and Northern Ireland; bordering Britain; and bordering the isles of Britain and Ireland.

In the context of the Irish border Brexit raised the possibility of border checkpoints on main arterial routes, hundreds of secondary cross-border road closures, and mobile border security patrols to control the movement of people and goods across it. However, the economic cost, practical difficulties and political risks in doing so mean that other options are worthy of exploration. An alternative option would be to hard border the isles of Britain and Ireland. Heretofore, the Irish Government has followed the UK Government on justice and home affairs issues. Such evidence suggests that Ireland could follow Britain's lead in hardening an isles of Britain and Ireland border zone. However, such a course of action would jeopardise Ireland's EU membership because it would present an affront to the EU's primary freedom of movement of labour principle. Furthermore, 'Irexit' would expose a

\footnotetext{
${ }^{24}$ Bertie Ahern in the Independent, 28 July 2017 at http://www.independent.co.uk/news/world/europe/ireland-bertie-ahern-brexit-britain-leave-eu-europeanunion-mad-republic-southern-irish-prime-a7864556.html (accessed 20/08/2017).
} 
small state to the vagaries of its asymmetrical relationship with a large and powerful neighbour devoted to seeking new economic and political relationships around the globe. From the perspective of Ireland, membership of the EC/EU has helped to calibrate the British-Irish relationship and protect Ireland's interests making the proposition of an Irexit 'mad'.

The least-worse option is to border Britain. The border of Britain is the UK border in the British national imagination. The border of Britain is an imagined border that is disseminated by the British media, endorsed by the political establishment, and is reflected in the British public attitudes. There are historical precedents for bordering Britain. This option would be problematic for the DUP in Northern Ireland and, potentially, for the Irish peace process if perceptions of Ulster British abandonment took hold. However, it would be relatively simple to establish and cause least disruption given the fact that border portals ports and airports - are already sites of identity checking and border security regimes. PostBrexit, bordering Britain for bodies with human faces is likely to happen regardless of the bordering option that is officially endorsed.

\section{Acknowledgements}

Thanks to John Coakley, Liam O'Dowd, and Special Issue Editor, Etain Tannam, who each commented on earlier drafts of this paper. The author acknowledges the support of the research project EUBORDERSCAPES (290775), 2012-2016, which was funded by the European Commission under the 7th Framework Programme (FP7-SSH-2011-1), Area 4.2.1 The evolving concept of borders.

\section{References}

Abell, Jackie, Susan Condor and Clifford Stevenson, 2006, “"We are an Island": Geographical Imagery in Accounts of Citizenship, Civil Society and National Identity in Scotland and England', pp. 207-226 in Political Psychology, vol. 27, no. 2. 
Amilhat Szary, Anne-Laure and Frédéric Giraut, 2015. 'Borderities: The Politics of Contemporary Mobile Borders', pp. 1-19 in Anne-Laure Amilhat Szary and Frédéric Giraut (eds.), Borderities and the Politics of Contemporary Mobile Borders. Basingstoke: Palgrave Macmillan.

Amoore, Louise, 2006. 'Biometric Borders: Governing Mobilities in the War on Terror', pp. 336-351 in Political Geography, vol. 25, no. 3.

Anderson, James and Liam O'Dowd, 2007. 'Imperial Disintegration and the Creation of the Irish Border: Imperialism and Nationalism 1885-1925', pp. 295-308 in Political Geography, vol. 26 , no. 8 .

Anderson, Malcolm with Eberhard Bort, 2001. The Frontiers of the European Union. Basingstoke: Macmillan.

Andreas, Peter, 2003. 'Redrawing the Line: Borders and Security in the Twenty-First Century', pp. 78-111 in International Security. vol. 28, no. 2.

Andreas, Peter, 2000. Border Games: Policing the US-Mexico Divide. Ithaca, NY and London: Cornell University Press.

Berezin, Mabel, 2003. 'Territory, Emotion and Identity', pp. 1-30 in Mabel Berezin and Martin Schain (eds.), Europe Without Borders: Remapping Territory, Citizenship and Identity in a Transnational Age. Baltimore: John Hopkins University.

Billig, Michael 1995. Banal Nationalism. London: Sage.

Broeders, Dennis, 2011. 'A European 'Border' Surveillance System Under Construction', pp. 40-67 in Huub Dijstelbloem and Albert Meijer (eds.), Migration and New Technological Borders of Europe. Basingstoke: Palsgrave Macmillan.

Buzan, Barry, 1993. 'State Security and Internationalization', pp. 41-58 in Ole Waever, Barry Buzan, Morten Kelstrup and Pierre Lemaitre (eds.), Identity, Migration and the New Security Agenda in Europe. London: Pinter.

Coakley, John, Brian Ó Caoindealbháin and Robin Wilson, 2007. 'Institutional Cooperation: the North-South Implementation Bodies', pp. 31-60 in John Coakley and Liam O'Dowd 
(eds.), Crossing the Border: New Relationships Between Northern Ireland and the Republic of Ireland. Dublin: Irish Academic Press.

European Commission, 2017. Joint report from the negotiators of the European Union and the United Kingdom Government on progress during phase 1 of negotiations under Article 50 TEU on the United Kingdom's orderly withdrawal from the European Union' (8 December 2017), TF50 (2017) 19 - Commission to EU 27. At https://ec.europa.eu/commission/publications/joint-report-negotiators-european-unionand-united-kingdom-government-progress-during-phase-1-negotiations-under-article-50teu-united-kingdoms-orderly-withdrawal-european-union_en (accessed 08/12/2017).

European Council, 2016. European Council Meeting (18 and 19 February 2016) Conclusions. Brussels: European Council. At http://www.consilium.europa.eu/en/press/press-releases/2016/02/19-euco-conclusions (accessed 24/02/2017).

Garry, John, 2017. 'Leo Varadkar: Irish Leader Reveals Fraying Patience Over Brexit Border' in the Conversation, 4 August 2017. At http://theconversation.com/leo-varadkar-irishleader-reveals-fraying-patience-over-brexit-border-82099 (accessed 20/08/2017).

Häkli, Jouni, 2015. 'The Border in the Pocket: The Passport as a Boundary Object', pp. 85-99 in Anne-Laure Amilhat Szary and Frédéric Giraut (eds.), Borderities and the Politics of Contemporary Mobile Borders. Basingstoke: Palgrave Macmillan.

Kassabova, Kapka, 2017. Border: A Journey Through the Edge of Europe. London: Granta Books.

Keating, Michael, 2016. 'Where Next for a Divided United Kingdom?, in the Irish Times, 2nd July.

Keating, Michael, 2010. The Government of Scotland: Public Policy Making after Devolution. Edinburgh: Edinburgh University Press.

Keating, Michael, 2004. 'European Integration and the Nationalities Question', pp. 367-388 in Politics \& Society, vol. 32 no. 3. 
Kilcourse, James, 2013. 'Ireland Raises its Voice in the UK's EU Debate', IIEA Blog, 6 November 2013. At www.iiea.com/blogosphere/ireland-raises-its-voice-in-the-uks-eudebate.

Kolossov, Vladimir, 2005. 'Border Studies: Changing Perspectives and Theoretical Approaches', pp. 606-632 in Geopolitics, vol. 10, no. 4.

Laffan, Brigid and Jane O'Mahony, 2008. Ireland and the European Union. Basingstoke: Palgrave Macmillan.

Laffan, Brigid and Diane Payne. 2001. Creating Living Institutions: EU Programmes After the Good Friday Agreement. Armagh: Centre for Cross Border Studies.

Laffan, Brigid, Rory O'Donnell and Michael Smith, 2000. Europe's Experimental Union: Rethinking Integration. London: Routledge.

Leary, Peter, 2016. Unapproved Routes: Histories of the Irish Border 1922-1972. Oxford: Oxford University Press.

Liddle, Roger, 2015. The Risk of Brexit: Britain and Europe in 2015. London: Rowan and Littlefield.

MacShane, Denis, 2015. Brexit: How Britain Will Leave Europe. London: I.B. Tauris.

McCall, Cathal, 2014. The European Union and Peacebuilding: The Cross-Border Dimension. Basingstoke: Palgrave Macmillan.

McCall, Cathal 2011. 'Culture and the Irish Border: Spaces for Conflict Transformation', pp. 201-221 in Cooperation and Conflict, vol. 46, no. 2.

Meehan, Elizabeth, 2014. Borders and Boundaries: The Irish Example, Centre on Constitutional Change blogspot. At

http://www.centreonconstitutionalchange.ac.uk/blog/borders-and-boundaries-irishexample (accessed 13/07/2016).

Meehan, Elizabeth, 2000. Free Movement between Ireland and the UK: from the "common travel area" to The Common Travel Area. Dublin: The Policy Institute. 
Nash, Catherine, Bryonie Reid and Brian Graham, 2013. Partitioned Lives: The Irish Borderlands.Farnham: Ashgate.

Newman, David, 2006. 'Borders and Bordering: Towards an Interdisciplinary Dialogue', pp. 171-186 in the European Journal of Social Theory, vol. 9, no. 2.

O'Ceallaigh, Dáithi and Paul Gillespie (eds.), 2015. Britain and Europe: The Endgame. Dublin: The Institute of International and European Affairs.

O'Ceallaigh, Dáithi and James Kilcourse. 2013. Untying the Knot: Ireland, the UK and the EU. Dublin: The Institute of International and European Affairs.

O’Dowd, Liam, 2002. 'The Changing Significance of European Borders', pp. 13-36 in Regional and Federal Studies, vol. 12, no. 4.

Patterson, Henry, 2013. Ireland's Violent Frontier: The Border and Anglo-Irish Relations During the Troubles. Basingstoke: Palgrave Macmillan.

Peoples, Columba and Nick Vaughan Williams, 2015. Critical Security Studies: An Introduction. London: Routledge.

Phinnemore, David and Lee McGowan, 2013. A Dictionary of the European Union. London: Routledge.

Pollak, Sorcha, 2016. 'Search After Young Man's Death Bonds Border Communities', in the Irish Times, 11 January.

Rose, Richard, 1983. Is the United Kingdom a State? Glasgow: Centre for the Study of Public Policy.

Ruane, J. and Todd, J. 2001. 'The Politics of Transition? Explaining Political Crises in the Implementation of the Belfast Good Friday Agreement', Political Studies, Vol. 49, 923-940.

Singham, Shanker, 2017. Austen Morgan, Victoria Hewson and Alice Brooks. How the UK and EU can resolve the Irish border issue after Brexit. London: Legatum Institute. At http://www.li.com/activities/publications/mutual-interest-how-the-uk-and-eu-can-resolvethe-irish-border-issue-after-brexit, p. 28 (accessed 08/12/2017). 
Sørensen, Georg, 1999. 'Sovereignty: Change and Continuity in a Fundamental Institution', pp. 590-604 in Political Studies, vol. 47.

Staunton, Denis, 2017. 'UK Rules out Moving Border to Irish Sea', in the Irish Times, 29th July.

Taylor, Charlie, 2017. 'Post-Brexit Tech Border Deemed 'Complete Nonsense' by IT Experts', in the Irish Times, 16 August. At http://www.irishtimes.com/business/technology/postbrexit-tech-border-deemed-complete-nonsense-by-it-experts-1.3188475 (accessed 20/08/2017).

van Houtum, Henk and Roos Pijpers, 2007. 'The European Union as a Gated Community: The Two-faced Border and Immigration Regime of the EU', pp. 291-309 in Antipode, Volume 39, Issue 2.

Vaughan-Williams, Nick, 2009. Border Politics: The Limits of Sovereign Power. Edinburgh: Edinburgh University Press.

Waever, Ole, 1996. 'European Security Identities', pp. 103-32 in the Journal of Common Market Studies, vol. 34, no. 1.

Waever, Ole, 1995. 'Securitization and Desecuritization', pp. 46-86 in Ronnie D. Lipschutz (ed.), On Security. New York: Columbia University Press.

Wallace, William, 1999. 'The Sharing of Sovereignty: The European Paradox', pp. 503-521 in Political Studies, vol. XLVII, no. 3.

Walsh, Dermot, 2011. 'Police Cooperation across the Irish Border: Familiarity Breeding Contempt for Transparency and Accountability', pp. 301-330.in the Journal of Law and Society, vol. 38, no. 2.

Walters, William, 2006. 'Border/Control', pp. 187-203 in the European Journal of Social Theory, vol. 9, no. 2. 
Words: 7808 